\title{
Competitive formation of spiro[5.5] undecane in preference to bicyclo[4.3.1]decane via type II carbonyl ene reaction
}

\author{
Adusumilli Srikrishna* and Chikkana Dinesh \\ Department of Organic Chemistry, Indian Institute of Science, Bangalore 560012, India
}

\begin{abstract}
The presence of an isopropenyl group at the C-1 position of a 3-isopropenylcyclohexaneacetaldehyde failed to generate the spiro[4.5]decane and produced only bicyclo[4.3.1]decanol. However, the presence of a methallyl group at the C-1 position of 3 -isopropenylcyclohexaneacetaldehyde generated exclusively the spiro[5.5]undecanols.
\end{abstract}

\section{Introduction}

Intramolecular ene reactions in which a carbonyl group serves as the enophile (commonly referred as carbonyl ene reactions ${ }^{1}$ ) have been widely used in synthesis for the construction of five-, six- and seven-membered rings. As in Diels-Alder reactions, Lewis acid catalysis via complexation with the carbonyl group increases the rate of the reactions making them useful in natural product synthesis. ${ }^{1}$ A cyclohexane ring containing acetaldehyde and isopropenyl side chains at the 1,3-positions in a cis orientation was found to be the ideal precursor for the synthesis of bicyclo[4.3.1]decanes via a carbonyl ene reaction. The enantioselective syntheses of several bicyclo[4.3.1]decanes 1 have been accomplished ${ }^{2}$ in an efficient manner starting from aldehydes 2 , which were obtained from the readily and abundantly available monoterpene $(R)$-carvone $\mathbf{3}$.

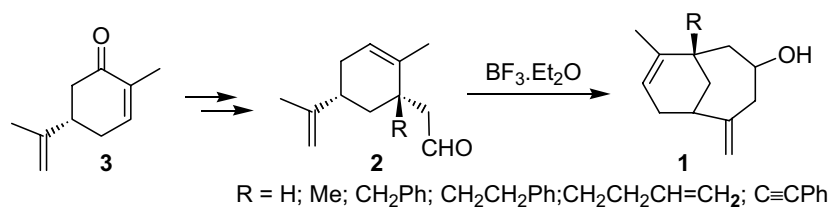

The presence of spiro fused systems, either simple or as part of a polycyclic carbon framework is commonly

\footnotetext{
*Corresponding author. Tel.: +91 80 22932215; fax: +91 80 23600683; e-mail: ask@orgchem.iisc.ernet.in
}

encountered in many natural products. ${ }^{3}$ In this context, it was decided to investigate the type II carbonyl ene reaction of aldehyde 4 . Since aldehyde $\mathbf{4}$ contains two isopropenyl groups at the $\mathrm{C}-1$ and $\mathrm{C}-3$ positions of a cyclohexaneacetaldehyde, one would lead to bi-cyclo[4.3.1]decane and the other to spiro[4.5]decane. This is an interesting precursor for assessing the utility of carbonyl ene reactions for the generation of a bridge system versus a spiro system.

\section{Results and discussion}

Aldehyde 4 was prepared from $(R)$-carvone 3 (Scheme 1). An alkylative enone transposition ${ }^{4}$ was employed for the generation of 3-isopropenylcarvone 6. Thus, the regioselective 1,2-addition of isopropenylmagnesium bromide to carvone 3 in THF followed by oxidation of the resultant tertiary bi-allylic alcohol $\mathbf{5}$ with a mixture of PCC and silica gel in methylene chloride cleanly generated the transposed dienone $\mathbf{6}$. Regioselective reduction of dienone $\mathbf{6}$ with LAH in ether at low temperature $\left(-70^{\circ} \mathrm{C}\right)$ furnished the syn allyl alcohol 7 , in a highly stereoselective $(>97 \%)$ manner, in which the stereochemistry of the allyl alcohol was assigned on the basis of the well established reduction of 5-substituted cyclohexenones. ${ }^{5}$ The ortho-ester Claisen rearrangement ${ }^{6}$ of allyl alcohol 7 with triethyl orthoacetate and a catalytic amount of propionic acid in a sealed tube at $180{ }^{\circ} \mathrm{C}$ furnished ester $\mathbf{8}$ in a stereoselective manner. Reduction of ester $\mathbf{8}$ with LAH followed by oxidation of the resultant primary alcohol with PCC and silica gel in methylene chloride furnished aldehyde 4. 


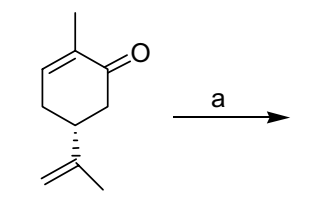

3

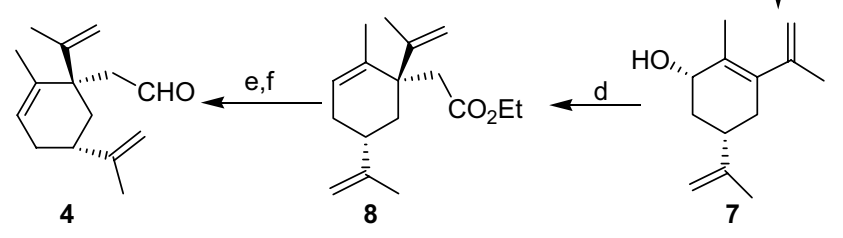

Scheme 1. Reagents, conditions and yields: (a) $\mathrm{CH}_{2}=\mathrm{C}(\mathrm{Me}) \mathrm{MgBr}$, THF, rt, $4 \mathrm{~h}$; (b) PCC, silica gel, $\mathrm{CH}_{2} \mathrm{Cl}_{2}, \mathrm{rt}, 6 \mathrm{~h} ; 63 \%$ (for two steps); (c) $\mathrm{LiAlH}_{4}, \mathrm{Et}_{2} \mathrm{O},-70{ }^{\circ} \mathrm{C}, 2 \mathrm{~h}, 90 \%$; (d) $\mathrm{MeC}(\mathrm{OEt})_{3}, \mathrm{EtCO}_{2} \mathrm{H}$, sealed tube, $180{ }^{\circ} \mathrm{C}, 4$ days, $70 \%$; (e) $\mathrm{LiAlH}_{4}, \mathrm{Et}_{2} \mathrm{O}, 0{ }^{\circ} \mathrm{C}, 0.5 \mathrm{~h}, 92 \%$; (f) $\mathrm{PCC}$, silica gel, $\mathrm{CH}_{2} \mathrm{Cl}_{2}, \mathrm{rt}, 2 \mathrm{~h}, 81 \%$.

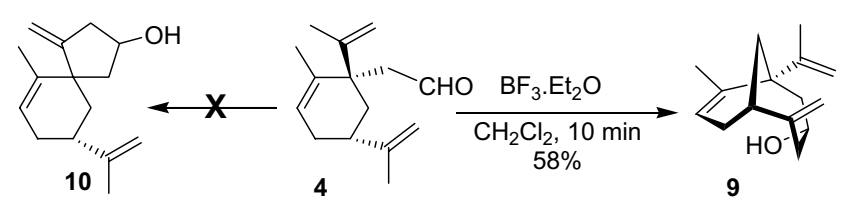

Treatment of a $0.005 \mathrm{M}$ solution of aldehyde 4 in methylene chloride with 0.5 equiv of boron trifluoride diethyl etherate at $5{ }^{\circ} \mathrm{C}$ for $10 \mathrm{~min}$ unexpectedly furnished only the endo-bicyclo[4.3.1]decenol 9 in a highly stereoselective ( $>95 \%$ by NMR) manner with no detectable amounts of the spiro[4.5]decane $\mathbf{1 0}$ being formed. The structure of alcohol 9 was established from its spectral data, and further confirmed by the oxidation of alcohol 9 with PCC and sodium acetate in methylene chloride to furnish ketone 11. Isomerisation of the exomethylene group in $\mathbf{1 1}$ with a catalytic amount of DBU in methylene chloride furnished the conjugated ketone 12. ${ }^{9}$

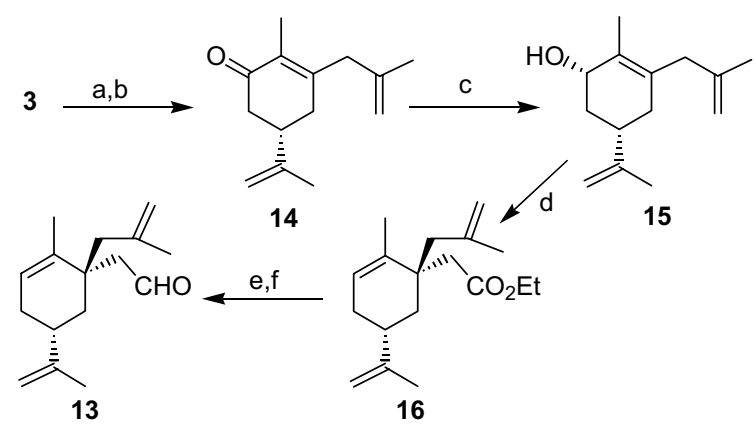

Scheme 2. Reagents, conditions and yields: (a) $\mathrm{CH}_{2}=\mathrm{C}(\mathrm{Me})-$ $\mathrm{CH}_{2} \mathrm{MgCl}$, THF, rt, $8 \mathrm{~h}$; (b) PCC, silica gel, $\mathrm{CH}_{2} \mathrm{Cl}_{2}, \mathrm{rt}, 8 \mathrm{~h} ; 65 \%$ (for two steps); (c) $\mathrm{LiAlH}_{4}, \mathrm{Et}_{2} \mathrm{O},-70{ }^{\circ} \mathrm{C}, 2 \mathrm{~h}, 95 \%$; (d) $\mathrm{MeC}(\mathrm{OEt})_{3}$, $\mathrm{EtCO}_{2} \mathrm{H}$, sealed tube, $180{ }^{\circ} \mathrm{C}, 3$ days, $60 \%$; (e) $\mathrm{LiAlH}_{4}, \mathrm{Et}_{2} \mathrm{O}, 0{ }^{\circ} \mathrm{C}, 1 \mathrm{~h}$, 90\%; (f) $\mathrm{PDC}, \mathrm{CH}_{2} \mathrm{Cl}_{2}, \mathrm{rt}, 2 \mathrm{~h}, 94 \%$.

(Scheme 2). Thus, a 1,2-addition of methallylmagnesium chloride to carvone 3 in $\mathrm{THF}$ at $0{ }^{\circ} \mathrm{C}$ followed by oxidation of the resultant alcohol with a mixture of PCC and silica gel in methylene chloride at room temperature generated enone 14. Stereo- and regioselective reduction of enone 14 with LAH followed by an ortho-ester Claisen rearrangement of allyl alcohol 15 with triethyl orthoacetate and a catalytic amount of propionic acid in a sealed tube at $180^{\circ} \mathrm{C}$ for 4 days generated ester $\mathbf{1 6}$. Reduction of ester 16 with LAH followed by oxidation of the primary alcohol with pyridinium dichromate (PDC) in methylene chloride furnished aldehyde 13. Treatment of a $0.005 \mathrm{M}$ solution of the aldehyde $\mathbf{1 3}$ in methylene chloride at $0-5^{\circ} \mathrm{C}$ with 0.5 equiv of boron trifluoride diethyl etherate for $10 \mathrm{~min}$ furnished exclusively $^{7}$ the spiro[5.5] undecanol 17 (Scheme 3). Comparison of the spectral data (IR, ${ }^{1} \mathrm{H}$ and ${ }^{13} \mathrm{C}$ NMR) with that of bicyclo[4.3.1]decanes 1 and 9 confirmed that the product formed is the spiro alcohol $\mathbf{1 7}$ and not 18. Oxidation of alcohol 17 with PCC and silica gel in methylene chloride furnished a mixture of ketone 19 and conjugated enone 20, which on treatment with a catalytic amount of DBU in methylene chloride at room temperature furnished the conjugated ketone $\mathbf{2 0}$.

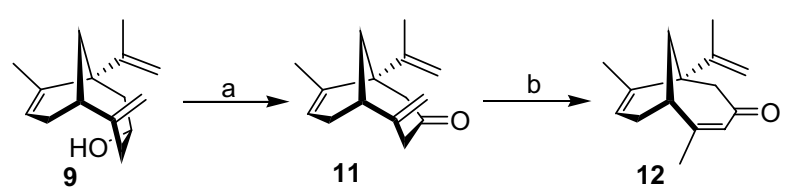

(a) PCC, $\mathrm{NaOAc}, \mathrm{CH}_{2} \mathrm{Cl}_{2}, \mathrm{rt}, 0.5$ h, $82 \%$; (b) DBU, $\mathrm{CH}_{2} \mathrm{Cl}_{2}, \mathrm{rt}, 3 \mathrm{~h}, 83 \%$.

Even though it is known that 3-methylenecyclopentanols could be generated from $\gamma, \delta$-unsaturated aldehydes via a Lewis acid catalysis, the reaction is supposed to proceed via a zwitterion mechanism, ${ }^{1 \mathrm{~b}}$ as the transition state for the concerted type II ene reaction is very strained, which explains the failure of the formation of the spiro system $\mathbf{1 0}$ from the aldehyde $\mathbf{4}$. To substantiate further, we turned our attention towards the homologous system 13, which could generate either the bicyclo[4.3.1]decane or the spiro[5.5] undecane via the type II carbonyl ene reaction. Accordingly, the methallyl group was chosen in place of the isopropenyl group
To further establish the strategy for the enantioselective synthesis of spiro[5.5]undecanes, the sequence was also carried out with dihydrocarvone 21. Thus, partial hydrogenation of $(R)$-carvone 3 with Wilkinson's catalyst ${ }^{8}$ in benzene at one atmospheric pressure furnished dihydrocarvone $\mathbf{2 1}$, which was transformed into aldehyde 22. Treatment of a $0.005 \mathrm{M}$ solution of aldehyde 22 in methylene chloride at $0-5{ }^{\circ} \mathrm{C}$ with 0.5 equiv of boron trifluoride diethyl etherate for 10 min furnished, as expected, the spiro[5.5] undecanol 23. ${ }^{7}$ Oxidation of alcohol 23 with PCC and silica gel in methylene chloride furnished ketone $\mathbf{2 4}$, which on isomerisation with a cat- 


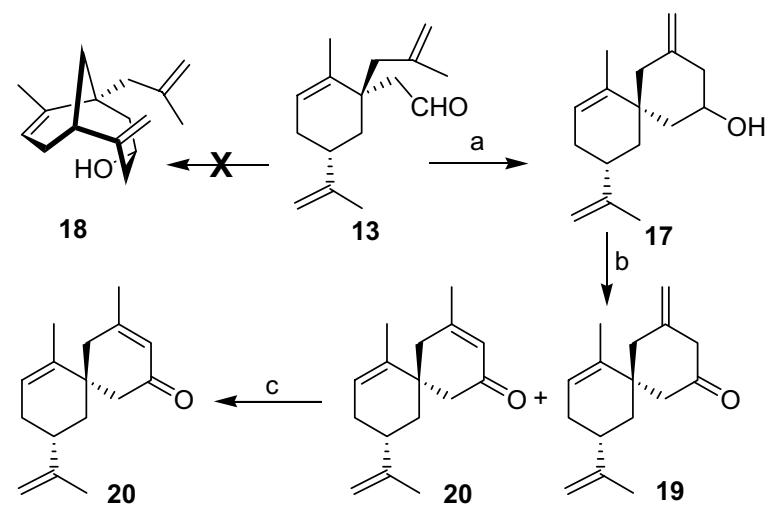

Scheme 3. Reagents, conditions and yields: (a) $\mathrm{BF}_{3} \cdot \mathrm{Et}_{2} \mathrm{O}, \mathrm{CH}_{2} \mathrm{Cl}_{2}$, $5{ }^{\circ} \mathrm{C}, 10 \mathrm{~min}, 43 \%$; (b) PCC, silica gel, $\mathrm{CH}_{2} \mathrm{Cl}_{2}, \mathrm{rt}, 2 \mathrm{~h}$; (c) DBU, $\mathrm{CH}_{2} \mathrm{Cl}_{2}, \mathrm{rt}, 2 \mathrm{~h}, 85 \%$ (two steps).

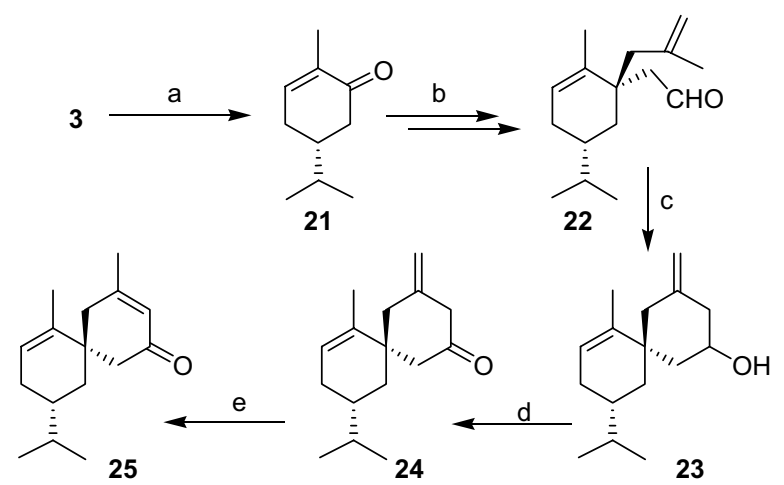

Scheme 4. Reagents, conditions and yields: (a) $\left(\mathrm{Ph}_{3} \mathrm{P}\right)_{3} \mathrm{RhCl}, \mathrm{C}_{6} \mathrm{H}_{6}$, $\mathrm{H}_{2}, 1 \mathrm{~atm}, \mathrm{rt}, 2$ days, $98 \%$; (b) as in Scheme 2; (c) $\mathrm{BF}_{3} \cdot \mathrm{Et}_{2} \mathrm{O}, \mathrm{CH}_{2} \mathrm{Cl}_{2}$, $5{ }^{\circ} \mathrm{C}, 10$ min, $60 \%$; (d) PCC, silica gel, $\mathrm{CH}_{2} \mathrm{Cl}_{2}$, rt, $2 \mathrm{~h}$; $83 \%$; (e) DBU, $\mathrm{CH}_{2} \mathrm{Cl}_{2}, \mathrm{rt}, 3 \mathrm{~h}, 92 \%$.

alytic amount of DBU in methylene chloride furnished spirodienone 25 (Scheme 4).

\section{Conclusion}

In conclusion, we have demonstrated that the formation of a spiro[4.5]decanol cannot compete with the formation of bicyclo[4.3.1]decane via a type II carbonyl ene reaction of a 1,3-diisopropenylcyclohexaneacetaldehyde. However, under the same conditions, 1-(2-methylallyl)3 -isopropenylcyclohexaneacetaldehyde exclusively generates the spiro[5.5]undecane. Currently, we are investigating the potential of this reaction for the enantioselective synthesis of natural products containing a spiro system.

\section{Acknowledgements}

We thank the council of scientific and industrial research, New Delhi, for the award of a research fellowship to C.D.

\section{References}

1. (a) Hoffmann, H. M. R. Angew. Chem., Int. Ed. Engl. 1969 , 8, 556; (b) Keung, E. C.; Alper, H. J. Chem. Educ. 1972, 49, 97; (c) Snider, B. B.; Rodini, D. J.; Straten, J. V. J. Am. Chem. Soc. 1980, 102, 5872; (d) Oppolzer, W.; Snieckus, V. Angew. Chem., Int. Ed. Engl. 1978, 17, 476; (e) Taber, D. F. Intramolecular Diels-Alder and Alder Ene Reactions; Springer: Berlin, 1984; (f) Snider, B. B. In Comprehensive Organic Synthesis; Trost, B. M., Fleming, I., Eds.; Pergamon Press: Oxford, 1992; Vol. 5, p 1; (g) Snider, B. B. Acc. Chem. Res. 1980, 13, 426; (h) Snider, B. B.; Rodini, D. J.; Karras, M.; Kirk, T. C.; Deutsch, E. A.; Cordova, R.; Price, R. T. Tetrahedron 1981, 37, 3927.

2. Srikrishna, A.; Dinesh, C.; Anebouselvy, K. Tetrahedron Lett. 1999, 40, 1031.

3. Sannigrahi, M. Tetrahedron 1999, 55, 9007.

4. Srikrishna, A.; Hemamalini, P. Indian J. Chem. 1990, 29B, 152.

5. (a) Wu, Y.-D.; Houk, K. N.; Florez, J.; Trost, B. M. J. Org. Chem. 1991, 56, 3656; (b) Garver, L.; van Eikeren, P.; Byrd, J. E. J. Org. Chem. 1976, 41, 2773.

6. Johnson, W. S.; Werthemann, L.; Bartlett, W. R.; Brocksom, T. J.; Li, T. T.; Faulkner, D. J.; Petersen, M. R. J. Am. Chem. Soc. 1970, 92, 741.

7. The ene reaction was found to be highly stereoselective ( $>95 \%$ by ${ }^{1} \mathrm{H}$ and ${ }^{13} \mathrm{C}$ NMR). However, since the next step is oxidation, no attempt was made to assign the stereochemistry of alcohols $\mathbf{1 7}$ and $\mathbf{2 3}$.

8. Ireland, R. E.; Bey, P. Org. Synth. 1973, 53, 63.

9. All the compounds exhibited the spectral data (IR, ${ }^{1} \mathrm{H}$ and ${ }^{13} \mathrm{C}$ NMR and mass) consistent with the structures. Yields refer to isolated and chromatographically pure compounds. Selected spectral data for the bicyclic enone 12: $[\alpha]_{\mathrm{D}}^{24}=-220\left(c \quad 0.5, \mathrm{CHCl}_{3}\right)$. IR (neat): $v_{\max } / \mathrm{cm}^{-1} 1666$, 902. ${ }^{1} \mathrm{H}$ NMR $\left(300 \mathrm{MHz}, \mathrm{CDCl}_{3}+\mathrm{CCl}_{4}\right): \delta 5.87(1 \mathrm{H}, \mathrm{s})$, $5.44(1 \mathrm{H}, \mathrm{d}, J=5.1 \mathrm{~Hz}), 4.80(1 \mathrm{H}, \mathrm{s}), 4.75(1 \mathrm{H}, \mathrm{s}), 2.93$ and $2.64(2 \mathrm{H}, \mathrm{AB} \mathrm{q}, J=15.0 \mathrm{~Hz}), 2.68(1 \mathrm{H}, \mathrm{s}), 2.50-2.30(1 \mathrm{H}$, $\mathrm{m}), 2.17(1 \mathrm{H}, \mathrm{t}$ of $\mathrm{d}, J=13.8$ and $3.5 \mathrm{~Hz}), 2.05-1.90(2 \mathrm{H}$, $\mathrm{m}), 1.96(3 \mathrm{H}, \mathrm{s}), 1.65(3 \mathrm{H}, \mathrm{s}), 1.48(3 \mathrm{H}, \mathrm{s}) .{ }^{13} \mathrm{C} \mathrm{NMR}$ $\left(75 \mathrm{MHz}, \mathrm{CDCl}_{3}+\mathrm{CCl}_{4}\right): \delta 200.0(\mathrm{C}), 155.3(\mathrm{C}), 150.0(\mathrm{C})$, $135.8(\mathrm{C}), 130.0(\mathrm{CH}), 121.8(\mathrm{CH}), 111.5\left(\mathrm{CH}_{2}\right), 53.0\left(\mathrm{CH}_{2}\right)$, $42.8(\mathrm{C}), 38.7\left(\mathrm{CH}_{2}\right), 38.5(\mathrm{CH}), 30.1\left(\mathrm{CH}_{2}\right), 27.4\left(\mathrm{CH}_{3}\right)$, $19.1\left(\mathrm{CH}_{3}\right), 19.0\left(\mathrm{CH}_{3}\right)$. Mass: $\mathrm{m} / \mathrm{z} 215(\mathrm{M}-1,5 \%), 119$ (25), 117 (20), 107 (30), 91 (35), 43 (100). For the spiroenone 20: $[\alpha]_{\mathrm{D}}^{22}=+44.2\left(c \quad 1.2, \mathrm{CHCl}_{3}\right)$. IR (neat): $v_{\max } / \mathrm{cm}^{-1} 1660, \quad 1645, \quad 885 .{ }^{1} \mathrm{H} \quad \mathrm{NMR} \quad(300 \mathrm{MHz}$, $\left.\mathrm{CDCl}_{3}+\mathrm{CCl}_{4}\right): \quad \delta \quad 5.81 \quad(1 \mathrm{H}, \quad$ br s), $5.44 \quad(1 \mathrm{H}, \quad \mathrm{d}$, $J=5.2 \mathrm{~Hz}), 4.62(1 \mathrm{H}, \mathrm{s}), 4.60(1 \mathrm{H}, \mathrm{s}), 2.62(1 \mathrm{H}, \mathrm{d}$, $J=15.6 \mathrm{~Hz}), 2.49(1 \mathrm{H}, \mathrm{d}, J=18.6 \mathrm{~Hz}), 2.00-1.70(6 \mathrm{H}$, $\mathrm{m}), 1.88(3 \mathrm{H}, \mathrm{s}), 1.64(3 \mathrm{H}, \mathrm{s}), 1.62(3 \mathrm{H}, \mathrm{s}), 1.12(1 \mathrm{H}, \mathrm{t}$, $J=12.9 \mathrm{~Hz}) .{ }^{13} \mathrm{C} \mathrm{NMR}\left(75 \mathrm{MHz}, \mathrm{CDCl}_{3}+\mathrm{CCl}_{4}\right): \delta 198.9$ (C), $158.8(\mathrm{C}), 148.7(\mathrm{C}), 136.9(\mathrm{C}), 125.7(\mathrm{CH}), 125.2(\mathrm{CH})$, $109.5\left(\mathrm{CH}_{2}\right), 48.4\left(\mathrm{CH}_{2}\right), 41.2(\mathrm{C}), 39.3\left(\mathrm{CH}_{2}\right), 37.9(\mathrm{CH})$, $37.5\left(\mathrm{CH}_{2}\right), 31.3\left(\mathrm{CH}_{2}\right), 24.7\left(\mathrm{CH}_{3}\right), 20.7\left(\mathrm{CH}_{3}\right), 19.3\left(\mathrm{CH}_{3}\right)$. For the spiroenone 25: $[\alpha]_{\mathrm{D}}^{24}=+64.0\left(c 0.8, \mathrm{CHCl}_{3}\right)$. IR (neat): $v_{\max } / \mathrm{cm}^{1} 1670 .{ }^{1} \mathrm{H}$ NMR (300 MHz, CDCl $3+\mathrm{CCl}_{4}$ ): $\delta 5.86(1 \mathrm{H}$, br s), $5.47(1 \mathrm{H}, \mathrm{d}, J=4.8 \mathrm{~Hz}), 2.66(1 \mathrm{H}, \mathrm{d}$, $J=15.6 \mathrm{~Hz}), 2.51$ and $2.12(2 \mathrm{H}, 2 \times \mathrm{d}, J=18.6 \mathrm{~Hz}), 2.10$ $1.80(3 \mathrm{H}, \mathrm{m}), 1.93(3 \mathrm{H}, \mathrm{s}), 1.75-1.55(2 \mathrm{H}, \mathrm{m}), 1.62(3 \mathrm{H}, \mathrm{s})$, $1.39(1 \mathrm{H}$, septet, $J=6.6 \mathrm{~Hz}), 0.90(1 \mathrm{H}, \mathrm{d}$ of $\mathrm{t}, J=12.5$ and $1.5 \mathrm{~Hz}), 0.83(6 \mathrm{H}, \mathrm{d}, \quad J=6.6 \mathrm{~Hz}) .{ }^{13} \mathrm{C}$ NMR $(75 \mathrm{MHz}$, $\left.\mathrm{CDCl}_{3}+\mathrm{CCl}_{4}\right): \delta 199.2(\mathrm{C}), 159.0$ (C), 137.0 (C), 125.6 $(\mathrm{CH}), 125.5(\mathrm{CH}), 48.5\left(\mathrm{CH}_{2}\right), 41.1(\mathrm{C}), 39.3\left(\mathrm{CH}_{2}\right), 36.8$ $(\mathrm{CH}), 36.2\left(\mathrm{CH}_{2}\right), 32.2(\mathrm{CH}), 29.5\left(\mathrm{CH}_{2}\right), 24.6\left(\mathrm{CH}_{3}\right), 20.0$ $\left(\mathrm{CH}_{3}\right), 19.5\left(\mathrm{CH}_{3}\right), 19.2\left(\mathrm{CH}_{3}\right)$. Mass: $\mathrm{m} / \mathrm{z} 232\left(\mathrm{M}^{+}\right.$, $\left.\mathrm{C}_{16} \mathrm{H}_{24} \mathrm{O}, 30 \%\right), 189$ (17), 161 (18), 150 (30), 135 (40), 121 (30), 107 (100), 93 (60), 91 (60). 